
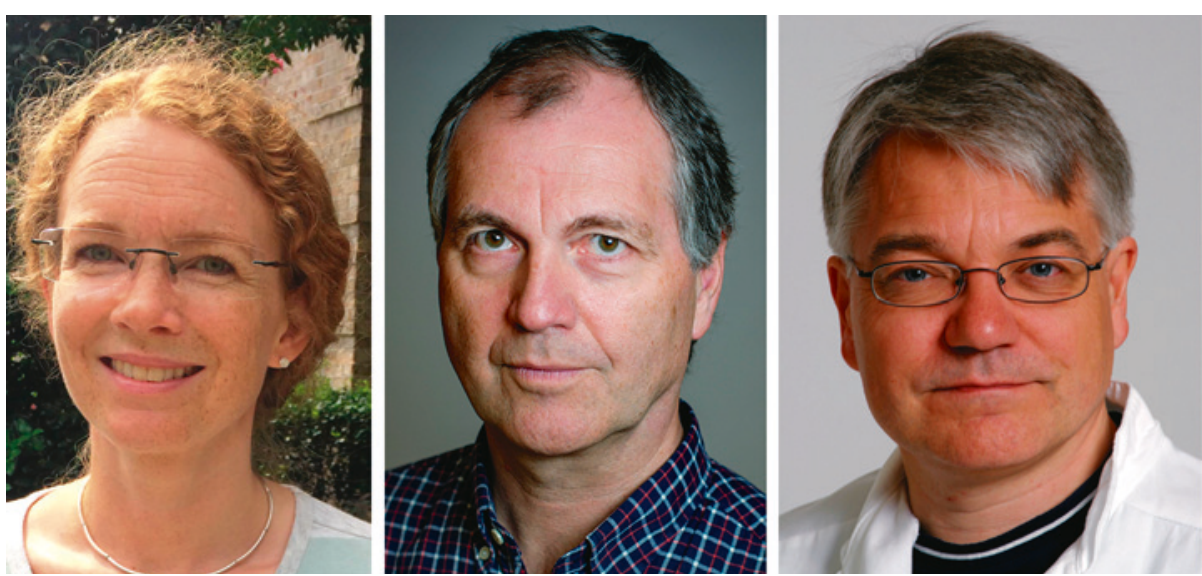

De tre norske forskerne bak studien. Fra venstre Mette C. Tollånes (foto: Frank Tollånes), Rolv Terje Lie (foto: Eivind Senneset) og Dag Moster (foto: Presseavdelingen, Universitetet i Bergen)

\title{
Cerebral parese og familiær risiko
}

Risikoen for cerebral parese øker med grad av slektskap til det rammede familiemedlem.

Cerebral parese er den vanligste grunnen til fysisk utviklingshemning hos barn. Årsaken er ofte ukjent, men risikofaktorer som bl.a. for tidlig fødsel, flerlingsvangerskap og fødselsasfyksi er identifisert. Det er påvist opphopning av cerebral parese i enkelte familier, noe som kan tyde på at arvelige årsaker spiller inn.

Forskere fra Universitetet i Bergen har nylig publisert en artikkel i $B M J$. Der presenteres i hvilken grad cerebral parese gjentas i familier (1). Det ble brukt data fra Medisinsk fødselsregister, og materialet inkluderte over to millioner barn født i perioden 1967-2003. Opplysninger om cerebral parese ble hentet fra Nav-registre over trygdeytelser, opplysninger om slektskapsforhold fra folkeregisteret.

Forekomsten av cerebral parese i hele materialet var 1,8 per 1000 , hos tvillinger 5,1 per 1000 . Dersom én tvilling var rammet, var det 15 ganger økt risiko hos den andre sammenliknet med risikoen i hele tvillingpopulasjonen (relativ risiko (RR) 15,6; $95 \%$ KI 9,8-25). Søsken av barn med cerebral parese hadde høyere risiko enn søsken av uaffiserte barn. Hos helsøsken (førstegradsslektninger) var risikoen ni ganger høyere (RR 9,2; 95 \% KI 6,4-13), hos halvsøsken (andregradsslektninger) var den tre ganger høyere (RR 3,0; $95 \% \mathrm{KI}$ $1,1-8,6)$, mens det hos søskenbarn (tredjegradsslektninger) var marginalt forhøyet risiko (RR 1,5; $95 \% \mathrm{KI} 0,9-2,7)$. Da man sammenliknet barn av foreldre med og barn av foreldre uten cerebral parese, var risikoen var seks ganger så høy hos barna med affiserte foreldre (RR 6,5; $95 \%$ KI 1,6-26). Når de for tidlig fødte ble ekskludert fra analysene, var funnene de samme.
- Studien viser at det i familier med ett tilfelle av cerebral parese er økt risiko for gjentakelse, med økende risiko jo nærere slektskapet er, sier førsteforfatter Mette C. Tollånes. - Dette kan skyldes arv og genetiske forhold, men familier deler også mye av samme miljø. Funnene kan tyde på multifaktoriell arv, der et samspill mellom flere gener og miljøfaktorer virker sammen og forårsaker sykdom, forklarer hun.

- Det er imidlertid viktig å huske på at absolutt risiko for cerebral parese er lav, også i familier der ett medlem allerede er rammet, legger hun til.

\section{Forskergruppen}

Tre norske forskere tilknyttet Universitetet i Bergen og Nasjonalt folkehelseinstitutt (Mette C. Tollånes, Rolv Terje Lie og Dag Moster) og en amerikansk forsker tilknyttet National Institute of Environmental Health Sciences (Allen Wilcox) står bak studien. Førsteforfatter Mette C. Tollånes er postdoktor ved Institutt for global helse og samfunnsmedisin ved Universitetet i Bergen. Medlemmene har tidligere samarbeidet flere ganger om studier innen perinatal epidemiologi, der de har benyttet data fra Medisinsk fødselsregister koblet med andre nasjonale registre.

\section{Lise Mørkved Helsingen}

Tidsskriftet

\section{Litteratur}

1. Tollånes MC, Wilcox AJ, Lie RT et al. Familial risk of cerebral palsy: population based cohort study. BMJ 2014: 349: g4294.
Ordforklaringer

Cerebral parese: Dette er en paraplybetegnelse på en gruppe tilstander som kjennetegnes av endret bevegelse og/eller stilling og motorisk funksjon, forårsaket av en skade i den umodne hjerne. Den vanligste årsak til fysisk utviklingshemning hos barn.

Multifaktoriell arv: Her er mer enn ett gen involvert, i tillegg kan miljøfaktorer virke inn.

Førstegradsslektninger: Betegnelse på nære blodsslektninger - et individs foreldre, helsøsken og barn.

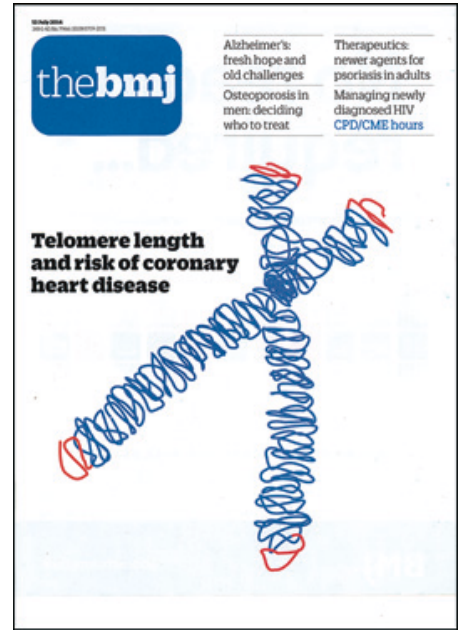

Artikkelen ble publisert 15.7. 2014 i BMJ, ett av de fem høyest rangerte medisinske tidsskriftene i verden 